\title{
Developing a family-reported measure of experiences with home-based pediatric palliative and hospice care: a multi-method, multi-stakeholder approach
}

Jackelyn Y. Boyden ${ }^{1,2^{*}}$ D, Chris Feudtner ${ }^{2,3}$, Janet A. Deatrick' ${ }^{1}$ Kimberley Widger ${ }^{4,5}$, Gwenn LaRagione ${ }^{2}$, Blyth Lord ${ }^{6}$ and Mary Ersek ${ }^{1,3,7}$

\begin{abstract}
Background: Many children with serious illnesses are receiving palliative and end-of-life care from pediatric palliative and hospice care teams at home (PPHC@Home). Despite the growth in PPHC@Home, no standardized measures exist to evaluate whether PPHC@Home provided in the U.S. meets the needs and priorities of children and their families.

Methods: We developed and conducted a preliminary evaluation of a family-reported measure of PPHC@Home experiences using a multi-method, multi-stakeholder approach. Our instrument development process consisted of four phases. Item identification and development (Phase 1) involved a comprehensive literature search of existing instruments, guidelines, standards of practice, and PPHC@Home outcome studies, as well as guidance from a PPHC stakeholder panel. Phase 2 involved the initial item prioiritization and reduction using a discrete choice experiment (DCE) with PPHC professionals and parent advocates. Phase 3 involved a second DCE with bereaved parents and parents currently receiving care for their child to further prioritize and winnow the items to a set of the most highly-valued items. Finally, we conducted cognitive interviews with parents to provide information about the content validity and clarity of the newly-developed instrument (Phase 4).
\end{abstract}

Results: Items were compiled predominantly from three existing instruments. Phase 2 participants included 34 PPHC providers, researchers, and parent advocates; Phase 3 participants included 47 parents; and Phase 4 participants included 11 parents. At the completion of Phase 4, the Experiences of Palliative and Hospice Care for Children and Caregivers at Home (EXPERIENCE@Home) Measure contains 22 of the most highly-valued items for evaluating PPHC@Home. These items include "The care team treats my child's physical symptoms so that my child has as good a quality of life as possible", "I have regular access to on-call services from our care team", and "The nurses have the knowledge, skills, and experience to support my child's palliative or hospice care at home."

(Continued on next page)

\footnotetext{
* Correspondence: boydenj@chop.edu

'School of Nursing, University of Pennsylvania, 418 Curie Blvd, Philadelphia, PA 19104, USA

${ }^{2}$ Children's Hospital of Philadelphia, 3401 Civic Center Blvd, Philadelphia, PA, USA

Full list of author information is available at the end of the article
}

(c) The Author(s). 2021 Open Access This article is licensed under a Creative Commons Attribution 4.0 International License, which permits use, sharing, adaptation, distribution and reproduction in any medium or format, as long as you give appropriate credit to the original author(s) and the source, provide a link to the Creative Commons licence, and indicate if changes were made. The images or other third party material in this article are included in the article's Creative Commons licence, unless indicated otherwise in a credit line to the material. If material is not included in the article's Creative Commons licence and your intended use is not permitted by statutory regulation or exceeds the permitted use, you will need to obtain permission directly from the copyright holder. To view a copy of this licence, visit http://creativecommons.org/licenses/by/4.0/. The Creative Commons Public Domain Dedication waiver (http://creativecommons.org/publicdomain/zero/1.0/) applies to the data made available in this article, unless otherwise stated in a credit line to the data. 
(Continued from previous page)

Conclusions: The EXPERIENCE@Home Measure is the first known to specifically measure family-reported experiences with PPHC@Home in the U.S. Future work will include formal psychometric evaluation with a larger sample of parents, as well as evaluation of the clinical utility of the instrument with PPHC@Home teams.

Keywords: Pediatric palliative care, Pediatric hospice care, Home-based care, Experience with care, Instrument development

\section{Background}

Children with serious illnesses, which may or may not have potential curative or life-prolonging treatments but all-too-often result in death [1], are generally living longer [2-4] and are increasingly being cared for by their families at home $[2,5,6]$ with the support of pediatric palliative and hospice care teams $[2,7,8]$. Pediatric palliative and hospice care at home, hereafter referred to as PPHC@Home, is palliative and hospice care provided primarily outside of the hospital, often integrating the care provided by different services in the home, outpatient, hospital, and hospice settings [9, 10]. PPHC@Home supports children and families by providing a wide spectrum of services, including pain and symptom management, psychosocial and emotional support for the child and family, on-call services, expressive and other therapies, and care coordination across medical and social service providers and institutions [9-14].

In the U.S., no standard model for PPHC@Home exists, but services are primarily provided by home hospice, home health care, or hospital-based pediatric palliative care (PPC) programs that conduct home visits. The composition of and services provided by these PPHC@Home programs are significantly influenced by state and local regulations and resources; therefore, PPHC@Home varies considerably across programs and geographic areas $[9,10,15,16]$.

In order to improve care for all children with serious illnesses and their families at home, the development of appropriate and feasible measures is critical [17]. More specifically, a family-reported measure of PPHC@Home is needed. A measure of patient and family perceptions of and experiences with the care they receive would provide invaluable information regarding the care provided, including if services meet patient and family priorities and expectations, as well as areas of unmet need and potential improvement for individual patients and families. Ultimately, providers, researchers, policymakers, and other stakeholders could use this information to improve the quality of care within and across programs $[18,19]$.

While several family-reported measures have been developed to evaluate PPC provided in hospital and community settings for children, these instruments were developed for populations outside the U.S. [20-22], where aspects of care differ due to varying health care system structures, funding mechanisms, cultural norms, social policies, and provider practices [23]. The application of these instruments to U.S.-based care may therefore not be appropriate. The one known existing instrument developed to measure PPHC@Home outcomes in a U.S-based program evaluates only one specific domain (namely, health-related quality of life) [24]. The development of a comprehensive family-reported experience measure of PPHC@Home provided in the U.S. is necessary to ensure that care teams are meeting children's and families' most important needs and priorities.

The purpose of this project was to develop and conduct a preliminary evaluation of a family-reported measure of experiences with PPHC@Home using a multimethod, multi-stakeholder approach. Starting with a consensus-based conceptual framework (described below), the project was conducted in four phases: Phase 1 - Item identification and development; Phase 2 - Initial prioritization and reduction of items by PPHC professionals; Phase 3 - Final prioritiztion and reduction of items by parents; and Phase 4 - Cognitive interviewing with parents. Since each phase built on results from the previous phase, the methods and results for each phase are presented together (Phases 2, 3, and 4). The Children's Hospital of Philadelphia's (CHOP) Institutional Review Board approved this study.

\section{Conceptual framework}

We used the National Consensus Project's (NCP) Clinical Guidelines for Quality Palliative Care (4th edition) [25] as a framework for this project. We adapted these general guidelines for the PPHC context using published PPC-specific practice guidelines [1, 17], standards of practice [26], and peer-reviewed literature [27], along with critical feedback by a panel of PPC stakeholders (providers and parent advocates), resulting in a total of 20 PPHC@Home domains (Table 1).

\section{Phase 1: item identification and development}

We identified items and developed the initial pool of items based on a comprehensive review of the literature on existing measures of PPHC@Home quality and outcomes. We conducted the initial biomedical librarianassisted literature search in Medline/Pubmed, CINAHL, 
Table 1 Domains of High-Quality Pediatric Palliative and Hospice Care at Home (PPHC@Home)

Domains
1. Access to care
3. Caregiver support at the end of life
4. Communication at the end of life
team
5. Coordination of care

6. Continuity of care

7. Cultural aspects of care

8. Ethical and legal aspects of care

9. Knowledge and skills of care team providers

10. Physical aspects of care: Communication

11. Physical aspects of care: Symptom management

12. Practical aspects of care

13. Psychological and emotional aspects of care: Child

14. Psychological and emotional aspects of care: Parent(s)

15. Psychological and emotional aspects of care: Sibling(s)

16.Psychological and emotional aspects of care: Extended social network

17. Relationship between family and care team

18. Social aspects of care: Child

19. Social aspects of care: Parent(s)

20. Spiritual and religious aspects of care

\section{Domain Definitions}

PPHC@Home team supports the child and family through access to palliative and hospice services 24 hours a day, 7 days a week

PPHC@Home team meets the spiritual, emotional, social, and cultural needs of family members at the end of life (for example, preparing parents and other family members for the child's end of life)

PPHC@Home team communicates with the child and family to develop and carry out a care plan to manage actual or potential symptoms at the end of life

PPHC@Home team communicates with the child and family to ensure that the care provided meets the child's and family's preferences, goals, values, and needs

PPHC@Home team works to ensure that when the child transfers between healthcare settings and providers, that there is appropriate and thorough communication of clinical information and child/ family goals, preferences, and values (for example, aligning needed in-home services, arranging for medical equipment)

PPHC@Home team works to ensure that the delivery of care is seamless across care settings and providers (for example, the same providers work with the family, providers across teams and organizations communicate regularly)

PPHC@Home team respects the child's and family's cultural and language needs and preferences

Child/family goals, preferences, and choices are respected within the limits of state and federal law, current medical care standards, and professional practice standards. These goals/preferences/ choices are also documented and shared with all professionals involved in the child's care

PPHC@Home team members have the appropriate education, training, and experience to provide high-quality in-home palliative and hospice care for seriously-ill children and families

PPHC@Home team provides information and education about treatments for the child's pain and other physical symptoms (for example, fatigue, nausea, constipation)

PPHC@Home team assesses and manages the child's pain and other physical symptoms, as well as any side effects of treatment, based on the best available medical evidence

PPHC@Home team supports the family through assistance and resources for navigating financialand insurance-related issues related to the child's care

PPHC@Home team assesses and manages the child's psychological and emotional issues and needs (such as anxiety, depression, distress, coping, grief) based on the best available medical evidence

PPHC@Home team helps to assess and manage parents' psychological and emotional issues and needs (such as anxiety, distress, coping, grief)

PPHC@Home team helps to assess and manage the sibling(s)' psychological and emotional issues and needs (such as anxiety, distress, coping, grief)

PPHC@Home team helps to assess and manage psychological and emotional issues (such as distress, coping, grief) of the family's greater familial and social community (e.g., extended family, friends, classmates)

Relationship between PPHC@Home team and the family is built on respect, trust, and advocacy for the child's and family's needs

PPHC@Home team helps navigate the child's social issues to meet child-family needs, promote child-family goals, and enhance child-family strengths and well-being (such as helping the child maintain and strengthen his/her social support network)

PPHC@Home team helps navigate parents' social issues to meet child-family needs, promote childfamily goals, and enhance child-family strengths and well-being (such as helping parents maintain and strengthen their social support network; helping parents develop strategies and access resources to balance caregiving, work, and family needs)

PPHC@Home team helps support child/family's religious and spiritual rituals or practices

Note: The above domains are based on the National Consensus Project's (NCP) Clinical Guidelines for Quality Palliative Care (4th edition) [25], which we further adapted using pediatric palliative care specific guidelines and the literature $[1,17,20,26,27]$ and using critical feedback from a panel of PPHC stakeholders (providers and parent advocates)

Scopus, and PsycINFO in February 2017 and updated this search in March 2018. Search terms included pediatric palliative, pediatric hospice, quality of care, quality measures, outcome measures, clinical assessment, tools, and instruments.
Out of nearly 200 papers, we identified three comprehensive instruments for evaluating PPC in the home and hospital settings in Canada, Germany, and Switzerland [20-22]. We supplemented the items from these instruments with additional items from four sources: first, the literature describing 
outcomes from PPHC@Home programs in the U.S. [11-13, 24, 27-30]; second, adult hospice quality measures [31, 32]; third, PPC-specific quality guidelines and standards of practice $[1,17,26]$; and fourth, general palliative care quality guidelines [25]. We compiled over 100 items from these sources. After removing duplicate and irrelevant items, we ended up with a pool of 70 items (Fig. 1 - Item Selection Process). The research team aligned each item with one of the 20 domains of PPHC@Home (Table 1).

We then reviewed the 70 items with a panel of five PPHC stakeholders (physician, nurse practitioner, social worker, and two bereaved parents/parent advocates) from across the U.S. Based on the panel's feedback, we revised items and added five new items for a total of 75 items for evaluation in Phase 2 (Fig. 1).

\section{Phase 2: initial prioritization and reduction of items by PPHC professionals}

\section{Methods}

To prioritize and reduce the number of candidate items for the measure, we conducted two discrete choice experiments (DCE). First, we conducted a DCE with PPHC

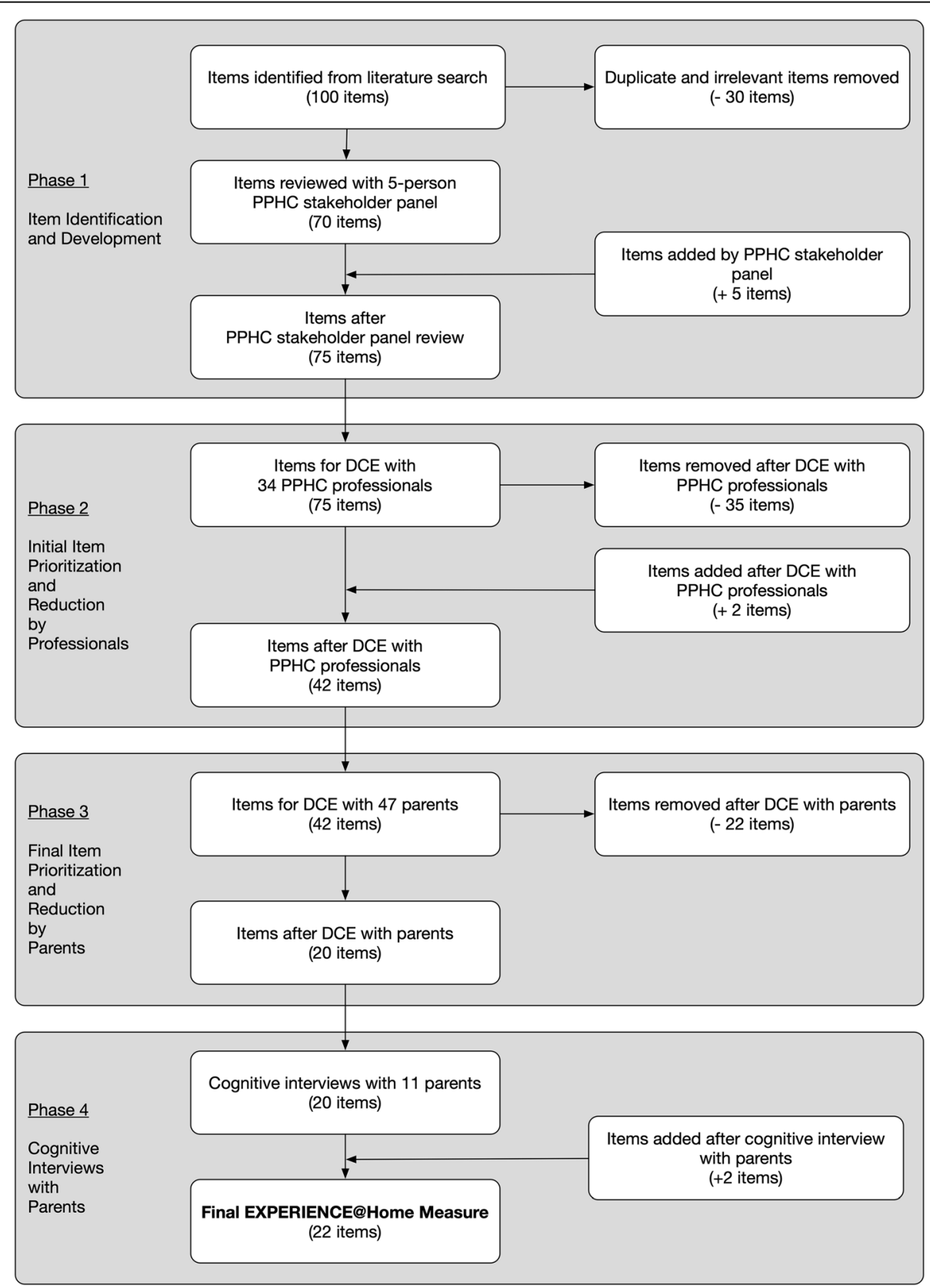

Fig. 1 Item Selection Process. Items added or removed during each phase of the instrument development process 
professionals (providers, researchers, and parent advocates) to reduce the initial item pool (Phase 2). Second, we conducted a DCE with parent participants to further prioritize and winnow the items (Phase 3, described in the following section).

\section{Overview of $D C E$}

DCE is a quantitative, choice-based approach to understanding individuals' stated preferences regarding choices related to healthcare [33-38] and consumer decision-making $[39,40]$. We chose a DCE over other group consensus techniques like Delphi methods because of known limitations of these other techniques, including the limited ability to discriminate between similarly-rated items and issues with scale-use bias that are inherent within rating scales [41, 42]. We used the DCE approach to obtain quantitative estimates of the relative importance of each item and domain (i.e., importance scores), and to rank order and winnow items. We used a DCE with Bandit MaxDiff Scaling, which is an approach that oversamples top-rated items to increase the precision of estimates of these items [42, 43]. This approach also minimizes sample size requirements and decreases the cognitive and time burden placed on participants by allowing each participant to rate a subset of the overall item pool, using Thompson Sampling to select the items for each new respondent based on estimates of each item's mean and variance from previous respondents $[42,43]$.

In both DCEs, participants were presented with sets of four items. Within each set, participants were instructed to choose which of the four items was the most important for supporting families caring for a child with serious illness at home, and which item was least important (Fig. 2 - Sample DCE Choice Set). This process was repeated across different sets, where participants chose the most and least important items among each set that contained a different four-item combination.

\section{Sample size considerations}

We used a DCE design that converges on stable estimates of the relative item scores with as few as 20 participants per subgroup [44, 45]. While no standard guidelines exist for defining sample sizes for these DCE studies, experts recommend simulation studies to test the effect of different sample sizes on the reliability of estimates [46]. We used a bootstrap approach, with replacement, to draw samples of 20,30 , and 50 respondents from a previous DCE study, conducted by one of the co-authors (CF), with a sample of 200 parents of children with serious illnesses [37]. We iterated this process 100 times for each of the three sample sizes and found that with a sample with as few as 30 respondents, high-rated items can be clearly differentiated from lowrated items. As a result, we aimed to recruit a minimum of 30 participants for each of the subsequent DCE phases (Phases 2 and 3).

\section{Recruitment and data collection}

Phase 2 participants were professionals who were recruited from hospital, community, and academic settings from the U.S. and Canada using the following inclusion criteria:

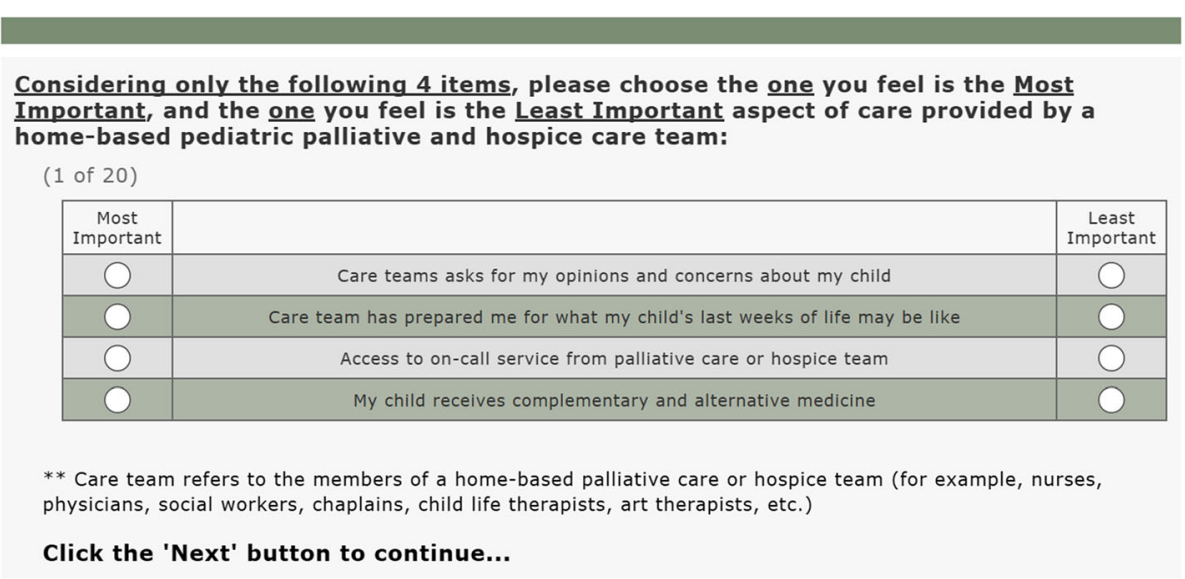

Fig. 2 Sample Discrete Choice Experiment (DCE) Choice Set. An example of a DCE choice set that professional and parent participants completed during Phases 2 and 3 of this study 
- For health care providers: member of an interdisciplinary PPC or hospice team (nurses, physicians, advanced practice nurses, social workers, child life therapists, art therapists, bereavement counselors, chaplains); palliative care or hospice board certification (physicians, nurses, advanced practice nurses) or $\geq 3$ years' clinical experience in PPC or hospice ( $\geq 0.5$ FTE); or established PPC researcher.

- For parent advocates: employed by a health system or parent advocacy organization, and has or has had a child who received PPHC@Home services.

Parent advocates were chosen for involvement in this early phase of the research because of their unique perspective that is based not only on their personal experiences with PPHC@Home, but also by their professional experiences working alongside families, providers, and other stakeholders. Our goal was to recruit 32 interdisciplinary professionals and at least four parent advocates.

Participants were recruited by the principal investigator (PI; co-author JB) via email. Interested participants contacted the PI and were emailed a web link for the discrete choice survey. They provided electronic informed consent to participate. If surveys were not completed after 1 week, the PI sent an electronic reminder. Each participant evaluated a subset of 30 items out of the overall 75 -item pool from Phase 1 that were displayed in 38 total sets, as well as the 20 PPHC@Home domains that were displayed in 15 sets, for 53 total sets. The entire survey took 30 to 35 minutes to complete.

\section{Analysis}

We determined the average ratings and rankings of items using Lighthouse Studio Version 9.6.1 (Sawtooth Software, Inc., Provo, UT), which used an aggregate logit application to multinomial logistic regression in order to estimate the average (mean) probability of choosing each item as most or least important across all participants (represented as a raw logit score). Raw logit scores were transformed to a 0 to 100 probability scale, where the lowest-rated item has a score of zero and scores for all items summed to 100 [42, 47]. This transformation facilitates a readily interpretable comparison of items, as this transformed score indicates the relative importance of items on a common scale (i.e., importance scores); for example, an item that is given a score of four is perceived by respondents as being twice as important as an item with a score of two. We then applied the same analytic process to calculate importance scores for each of the 20 PPHC@Home domains (Table 1).

To winnow the number of items, we first rank-ordered the domains by domain importance scores and calculated a maximum number of items "allowed" in each domain based on these importance scores. To estimate this maximum allowance, we multiplied the domain importance score by a "budget" value of 50 items (that is, our target maximum number of items for evaluation in the subsequent phase). As a result, all domains had an item allowance between 1 and 5 items. We then rank-ordered items by item-importance score, and retained the top-ranked items from each domain based on each domain's item allowance.

\section{Results}

Thirty-four PPC professionals participated in this phase, representing all interdisciplinary roles and 3 parent advocates (Table 2). Fifty percent of these professionals practiced in a hospital-based setting (inpatient and outpatient), $26.5 \%$ worked primarily in the home setting, $5.9 \%$ worked in both home and hospital settings, and $8.8 \%$ were primarily in an academic setting. Over $60 \%$ of our sample had eight or more years of PPC or hospice experience.

Additional file 1 presents the top-ranked items, which included $I$ trust the care team (Mean score 3.50; SE: 1.27), Access to on-call services from palliative care or hospice team (Mean score 3.04; SE: 1.26), and Care team helps me do the best for my child (Mean score 3.01; SE: 1.28). Lowest-ranked items included Care team helps prepare my child for school (Mean score 0.09; SE: 1.44), Care team keeps me informed about their arrival time (Mean score 0.07; SE: 1.50), and Care team helps with arranging transportation (Mean score 0.05; SE: 1.54).

In terms of relative importance, professionals rated the item I trust the care team (Mean score 3.50; SE: 1.27) as approximately twice as important as Care team helps me to advocate for my child's needs (Mean score 1.80; SE: 1.30), which is twice as important as Care team provides support for my spiritual needs (Mean score 0.92; SE: 1.35) (Additional file 1).

The top three domains included Physical Aspects of Care: Symptom Management (Mean score 11.20; SE: 5.04), Psychological/Emotional Aspects of Care: Child (Mean score 10.55; SE: 5.04), and Psychological/Emotional Aspects of Care: Parent(s) (Mean score 8.21; SE: 5.01). Lowest-ranked domains included Social Aspects of Care: Child (Mean score 1.61; SE: 5.01), Practical Aspects of Care (Mean score 1.60; SE: 5.00), and Emotional Aspects of Care: Extended Social Network (Mean score 0.36; SE: 5.17) (domain scores not depicted).

Top-ranked items in each domain were retained based on each domain's item allowance (Additional File 1; bolded items). Two new items were added to two domains, Physical Aspects of Care: Symptom Management and Psychological/Emotional Aspects of Care: Child, which had high importance scores, but not enough items 
Table 2 Characteristics of Professional Participants (Phase 2)

\begin{tabular}{|c|c|c|}
\hline \multicolumn{2}{|c|}{ Participant Characteristics $(n=34)$} & \multirow{2}{*}{$\frac{\text { No. (\%) }}{48.4(9.7)}$} \\
\hline Age (years) & Mean (SD) & \\
\hline \multirow[t]{2}{*}{ Gender } & Female & $\begin{array}{l}31 \\
(91.2 \%)\end{array}$ \\
\hline & Male & $3(8.8 \%)$ \\
\hline \multirow[t]{3}{*}{ Race } & Asian & $2(5.9 \%)$ \\
\hline & Black or African American & $1(2.9 \%)$ \\
\hline & White & $\begin{array}{l}31 \\
(91.2 \%)\end{array}$ \\
\hline Ethnicity & Non-Hispanic & $34(100 \%)$ \\
\hline \multirow[t]{8}{*}{ Professional Role } & Chaplain & $6(17.6 \%)$ \\
\hline & Expressive Therapist & $1(2.9 \%)$ \\
\hline & Nurse & $2(5.9 \%)$ \\
\hline & Nurse practitioner & $5(14.7 \%)$ \\
\hline & Parent Advocate & $3(8.8 \%)$ \\
\hline & Physician & $9(26.5 \%)$ \\
\hline & Researcher & $3(8.8 \%)$ \\
\hline & Social Worker & $5(14.8 \%)$ \\
\hline \multirow[t]{6}{*}{ Primary practice setting } & Academic & $3(8.8 \%)$ \\
\hline & $\begin{array}{l}\text { Hospital (inpatient, } \\
\text { outpatient) }\end{array}$ & $\begin{array}{l}17 \\
(50.0 \%)\end{array}$ \\
\hline & Home & $9(26.5 \%)$ \\
\hline & Home and Hospital & $2(5.9 \%)$ \\
\hline & Not applicable & $2(5.9 \%)$ \\
\hline & Other & $1(2.9 \%)$ \\
\hline \multirow[t]{3}{*}{ Years of PPC experience } & 3 to 7 years & $\begin{array}{l}13 \\
(38.2 \%)\end{array}$ \\
\hline & 8 to 10 years & $7(20.6 \%)$ \\
\hline & More than 10 years & $\begin{array}{l}14 \\
(41.2 \%)\end{array}$ \\
\hline \multirow[t]{5}{*}{$\begin{array}{l}\text { Geographic region of } \\
\text { practice }\end{array}$} & Northeast (U.S.) & $\begin{array}{l}11 \\
(32.4 \%)\end{array}$ \\
\hline & South (U.S.) & $\begin{array}{l}10 \\
(29.4 \%)\end{array}$ \\
\hline & Midwest (U.S.) & $7(20.6 \%)$ \\
\hline & West (U.S.) & $5(14.7 \%)$ \\
\hline & Canada & $1(2.9 \%)$ \\
\hline
\end{tabular}

in the item pool to fill these domains. In total, 42 items were retained for further evaluation (Fig. 1).

\section{Phase 3: final prioritization and reduction of items by parents Methods}

Recruitment and data collection

Parents were recruited from the CHOP Pediatric Advanced Care Team's (PACT) service area and from the online Courageous Parents Network (CPN), which is a virtual community of parents, families, and clinicians that provides information, skills, tools, and other resources to support parents and families during their child's illness journey. Participants were Englishspeaking parents over the age of 18 who had a child with a serious illness and who was younger than 25 years at the time care was received. Parents whose child was currently receiving PPHC@Home, as well as bereaved parents whose child had previously received PPHC@Home, were included in this study. For bereaved parents, we did not specify requirements for minimum length of time since their child's death. Previous research with bereaved parents and other family caregivers have found that participation in research is generally not distressing for participants [48, 49], even as soon as 2 weeks after the patient's death [50]. In agreement with previous studies, we believed parents should have the autonomy to decide whether or not they would participate $[48,49]$. Additionally, while issues with memory and recall may occur over time, participants often remember details about poignant events like the death of a loved one [51]. Since we were seeking parents' overall impression of what was important/not important for families at home, rather than specific details about their child's care, we did not limit the maximum length of time following a child's death.

The PI identified CHOP-based participants with the assistance of PACT's nurse coordinator and social worker and then contacted eligible parents by phone. Interested parents provided electronic informed consent and completed the web-based discrete choice survey concurrently by phone or in-person with the PI, or independently via a web link. The PI recruited participants from CPN with the assistance of CPN's staff, who posted recruitment materials and promoted the study through CPN's email database and social media page. Interested participants reached out to the PI via phone or email and completed the survey via an emailed web link. Parents were contacted a maximum of three times. All parents were compensated for their participation with a $\$ 30$ gift card.

In the DCE survey, participants provided their mostleast important ratings on a subset of 20 items out of the 42 -item pool and on the 20 domains. Items were displayed in different combinations of four items per set over 20 sets, and domains were displayed in different combinations of four domains per set over 15 sets. Participants, therefore, rated 35 sets that took 20 to $30 \mathrm{~min}$ to complete.

\section{Analysis}

We had three goals at this phase, namely to winnow the item pool to include only the highest-priority items, but also to ensure that in the final set of items, each domain was represented in a manner proportional to the rated 
importance of each domain, and that no single domain was over-represented. We therefore calculated weighted item scores, multiplying each item's individual score by the importance score for the item's associated domain, and capped each domain at a maximum of two items to avoid overrepresentation of any domain in the instrument. We then retained the top-rated items by weighted importance score, in keeping with the domain cap.

\section{Results}

Forty-seven parents from 45 families participated in this phase. Participants had a mean age of 42.6 years (SD $8.5)$, and most were white $(89.4 \%)$, college-educated (68.1\% college graduates) mothers (93.6\%). Most parents (87.2\%) were married or partnered and $48.9 \%$ were employed full-time (Table 3).

Approximately $70 \%$ of parents were currently caring for their child at home, and over one-third of children received care at home for more than 2 years. Over $50 \%$ of children were between 10 and 25 years of age. While children had a range of diagnoses, $51.1 \%$ had a neuromuscular, neurologic, or mitochondrial disease and $48.9 \%$ had a genetic or congenital disease (note: disease groups not mutually exclusive). We did not systematically collect information about the child/family's geographic location, although we know that participants received care in several geographic regions of the U.S. (Table 3).

Parent participants' prioritization of the domains are described elsewhere [52]. In brief, highest-ranked domains included Physical Aspects of Care: Symptom Management, Psychological/Emotional Aspects of Care: Child, and Care Coordination [52]. We then calculated weighted item scores and retained the top 20 items. While we capped each domain at 2 items, some domains, as expected, did not have any top-ranked items and were thus removed from the instrument [44]. Domains that were removed included Psychological/Emotional Aspects of Care: Sibling(s), Extended Social Network; Social Aspects of Care: Parent(s), Child; Practical Aspects of Care; Ethical and Legal Aspects of Care; Spiritual, Religious, and Existential Aspects of Care; and Cultural Aspects of Care. Top-ranked items by weighted score included Care team treats my child's physical symptoms so that my child has as good a quality of life as possible, I feel prepared to treat my child's symptoms at home, and My child can easily get necessary care (Table 4). In total, 20 items were retained for further evaluation in Phase 4 (Table 4; bolded items).

\section{Phase 4: cognitive interviews with parents Methods}

To examine the clarity of items and the measure's content validity, we conducted cognitive interviews [56] with 11 parents.

\section{Recruitment and data collection}

Parent participants met the same inclusion criteria as Phase 3, and a sub-group of participants were recontacted from Phase 3. After agreeing to participate, parents engaged in an in-person, phone-based, or videobased interview with the PI. With consent, interviews were audio-recorded and professionally transcribed. The structured interviews included specific probes about each item and about the overall instrument. Participants provided their interpretation of each item, their feedback on the relevance of items and comprehensiveness of the overall instrument, and their perceptions of issues regarding the clarity of the items and the overall instrument. Participants were compensated for their participation with a $\$ 30$ gift card.

\section{Analysis}

We followed Knafl et al.'s (2007) protocol for analysis [56]. We first summarized data item-by-item across participants to reflect parents' understanding and interpretation of each item and to identify potential problems (e.g., limited applicability, unclear reference or perspective, problems with wording/tone) with each item. We then summarized item interpretations and problems in a summary matrix. The PI and co-author JD reviewed all items and decided whether to retain, revise, or omit each item and whether to add new items. These decisions were discussed with the research team.

\section{Results}

Eleven parents participated, two of whom also participated in Phase 3. Participants' sociodemographic and children's clinical characteristics resembled that of Phase 3 participants, although a larger proportion of families in this phase had received PPHC@Home for a longer period of time (Additional File 2).

Interviews lasted, on average, 81 min (range: 53 to 106 min). We revised several items because parents interpreted the meaning in a way that was not our intent, felt that the item did not apply to families in their situation, or felt the wording to be insensitive or inappropriate. For example, three parents felt that the item The care team has prepared me for what my child's last weeks of life may be like was not applicable to their child's rare disease since clinicians were not able to provide an accurate idea of what to expect at the end of life, and, thus, were not able to provide this type of preparation or guidance (code: limited applicability). Additionally, three parents did not like the word "prepare" because, as one parent noted, "I'm not sure that any [parent] would ever say that...I feel ready for that" (code: problems with wording). Based on these parents' suggestions, we revised this item to The care team has talked with me about my child's last weeks of life and what they may be 
Table 3 Demographic and Clinical Characteristics of Parent Participants and Their Children (Phase 3)

Parents' Characteristics $(n=47)$

Parent type

Age (at time of study or at time of death)

Race

Ethnicity

Highest Education Level Completed

Relationship Status

Number of Other Children

Employment Status

Bereavement Status

Affiliation

Children's Characteristics ( $n=45$ )

Age

Gender

Race

Ethnicity
No. (\%)

$44(93.6 \%)$

$3(6.4 \%)$

$42.6(8.5)$

$42(89.4 \%)$

1 (2.1\%)

$3(6.4 \%)$

$1(2.1 \%)$

$43(91.5 \%)$

$3(6.4 \%)$

$1(2.1 \%)$

$1(2.1 \%)$

$2(4.3 \%)$

4 (8.5\%)

8 (17.0\%)

$19(40.4 \%)$

$13(27.7 \%)$

$41(87.2 \%)$

6 (12.8\%)

11 (23.4\%)

35 (74.5\%)

1 (2.1\%)

23 (48.9\%)

5 (10.6\%)

17 (36.2\%)

2 (4.3\%)

14 (29.8\%)

33 (70.2\%)

$16(34.0 \%)$

31 (66.0\%)

No. (\%)

8 (17.8\%)

9 (20.0\%)

5 (11.1\%)

17 (37.8\%)

6 (13.3\%)

21 (46.7\%)

24 (53.3\%)

$37(82.2 \%)$

2 (4.4\%)

5 (11.1\%)

1 (2.2\%)

$39(86.7 \%)$

$4(8.9 \%)$

2 (4.4\%) 
Table 3 Demographic and Clinical Characteristics of Parent Participants and Their Children (Phase 3) (Continued)

\begin{tabular}{|c|c|c|}
\hline Parents' Characteristics $(n=47)$ & & No. (\%) \\
\hline \multirow{9}{*}{$\begin{array}{l}\text { Primary complex chronic condition } \\
\text { (Note: not mutually exclusive; thus, the \% does not sum to } 100 \%)\end{array}$} & Cardiovascular & $10(22.2 \%)$ \\
\hline & Gastrointestinal & $4(8.9 \%)$ \\
\hline & Genetic or congenital & $22(48.9 \%)$ \\
\hline & Hematologic or immunologic & $4(8.9 \%)$ \\
\hline & Malignancy & $5(11.1 \%)$ \\
\hline & Metabolic & $10(22.2 \%)$ \\
\hline & Neuromuscular, neurologic, or mitochondrial & $23(51.1 \%)$ \\
\hline & Respiratory & $6(13.3 \%)$ \\
\hline & Other/Unknown & $1(2.2 \%)$ \\
\hline \multirow[t]{3}{*}{ Primary care team (hospice v. palliative care) } & Hospice & $19(42.2 \%)$ \\
\hline & Palliative Care & $24(53.3 \%)$ \\
\hline & Unknown/Not sure & $2(4.4 \%)$ \\
\hline \multirow[t]{6}{*}{ Length of time receiving home-based palliative or hospice care } & Less than 1 month & $5(11.1 \%)$ \\
\hline & 1 to 3 months & $5(11.1 \%)$ \\
\hline & 4 to 6 months & $7(15.6 \%)$ \\
\hline & 7 to 12 months & $5(11.1 \%)$ \\
\hline & 1 to 2 years & $8(17.8 \%)$ \\
\hline & More than 2 years & $15(33.3 \%)$ \\
\hline
\end{tabular}

like. Overall, we retained the original wording for five items, made minor revisions to 10 items (i.e., changes in one or two words), and made more substantial revisions to five items (i.e., changes in three or more words or otherwise substantial re-organization of the item).

While parents thought that the instrument was comprehensive, five parents suggested that we add an item assessing emotional support for siblings. As a result, we added the item The care team provides support for my other children's feelings and emotions (Associated domain: Psychological and Emotional Aspects of Care: Sibling(s)). Additionally, while only one parent suggested an item about broad support for the parent caregiver, we agreed that this was a critical gap in the instrument and developed a new item, The care team has provided or directed me to resources that support my needs as my child's caregiver (Related domains: Psychological and Emotional Aspects of Care: Parent(s), Social Aspects of Care: Parent(s); Caregiver Support at the End of Life). These new items were not cognitively tested with parents in this study. Ultimately, 22 items were retained as the final version of the Experiences of Palliative and Hospice Care for Children and Caregivers at Home (EXPERIENCE@Home) Measure (Table 5).

\section{Discussion}

Employing a multi-method, multi-stakeholder approach for instrument development, we have developed the 22item EXPERIENCE@Home Measure, which measures families' experiences with PPHC@Home in the U.S. We began with broad palliative care guidelines and the peerreviewed PPC and PPHC@Home literature and incorporated the perspectives of different stakeholders. To our knowledge, this is the first published study to have used a DCE approach for health care instrument development.

A strength of the EXPERIENCE@Home instrument is the multiple perspectives used to develop the items, including existing guidelines, peer-reviewed literature, and instruments; interdisciplinary PPHC professionals, researchers, and parent advocates; and bereaved parents and parents who are currently caring for their child at home. For example, we developed the item, The care team treats my child's physical symptoms so that my child has as good a quality of life as possible, based on NCP Guidelines' recommendation for assessing "physical symptoms and their impact on well-being, quality of life, and functional status." [25] Our item not only evaluates whether or not a child's physical symptoms were treated, as in existing instruments [21, 22, 24, 53, 57], but additionally, if treatment was perceived as effective - that is, if symptoms were treated in a way that the child could enjoy as good a quality of life as possible. This emphasis on quality of life was a priority for parents in our study, who rated this item as the most important (nearly twice as important as the next most important item) (Table 4). In cognitive interviews, parents emphasized the importance of treating symptoms so that their child could remain a part of family life and participate in social activities at school and in the community. Parents in other studies have also reported that PPHC@Home 
Table 4 Items Prioritized by Parents (Phase 3)

\begin{tabular}{|c|c|c|c|}
\hline Item $^{a}$ & Domain $^{b}$ & $\begin{array}{l}\text { Weighted } \\
\text { Item } \\
\text { Score }\end{array}$ & Original Instrument \\
\hline $\begin{array}{l}\text { 1. Care team treats my child's physical symptoms } \\
\text { so that my child has as good a quality of life as } \\
\text { possible. }\end{array}$ & $\begin{array}{l}\text { Physical aspects of } \\
\text { care: Symptom } \\
\text { management }\end{array}$ & 61.08 & $\begin{array}{l}\text { New item after Phase } 2 \text { analysis (NCP 4th Edition } \\
\text { Domains) [25] }\end{array}$ \\
\hline $\begin{array}{l}\text { 2. I feel prepared to treat my child's symptoms at } \\
\text { home }\end{array}$ & $\begin{array}{l}\text { Physical aspects of } \\
\text { care: Symptom } \\
\text { management }\end{array}$ & 35.47 & Massachusetts PPCN Evaluation (Bona, 2011) [11] \\
\hline 3. My child can easily get necessary care & Access to care team & 30.30 & $\begin{array}{l}\text { Seattle Pediatric Palliative Care Project evaluation } \\
\text { (Hays, 2006) [30] }\end{array}$ \\
\hline $\begin{array}{l}\text { 4. Care team uses medicines to ease my child's pain } \\
\text { and other symptoms. }\end{array}$ & $\begin{array}{l}\text { Physical aspects of } \\
\text { care: Symptom } \\
\text { management }\end{array}$ & 27.50 & Parental PELICAN Questionnaire (Zimmerman, 2015) [22] \\
\hline 5. I trust the care team & $\begin{array}{l}\text { Relationship } \\
\text { between family and } \\
\text { care team }\end{array}$ & 26.94 & $\begin{array}{l}\text { Quality of Children's Palliative Care Instrument } \\
\text { (Widger, 2015) [53] }\end{array}$ \\
\hline $\begin{array}{l}\text { 6. Care team works together with me and my } \\
\text { child to make medical decisions }\end{array}$ & $\begin{array}{l}\text { Relationship } \\
\text { between family and } \\
\text { care team }\end{array}$ & 26.19 & $\begin{array}{l}\text { Parental PELICAN Questionnaire (Zimmerman, 2015) } \\
\text { [22]; Seattle Pediatric Palliative Care Project } \\
\text { evaluation (Hays, 2006) [30] }\end{array}$ \\
\hline 7. Care team helps me do the best for my child & $\begin{array}{l}\text { Relationship between } \\
\text { family and care team }\end{array}$ & 24.43 & New item (PPHC expert panel, Sept 2018) \\
\hline $\begin{array}{l}\text { 8. Care teams asks for my opinions and concerns } \\
\text { about my child }\end{array}$ & $\begin{array}{l}\text { Communication } \\
\text { between family and } \\
\text { care team }\end{array}$ & 24.20 & $\begin{array}{l}\text { Quality of Children's Palliative Care Instrument } \\
\text { (Widger, 2015) [53] }\end{array}$ \\
\hline $\begin{array}{l}\text { 9. Care teams are all working towards the same } \\
\text { goals for my child's care }\end{array}$ & Continuity of care & 24.10 & $\begin{array}{l}\text { Quality of Children's Palliative Care Instrument } \\
\text { (Widger, 2015) [53] }\end{array}$ \\
\hline $\begin{array}{l}\text { 10. Care team gives me enough information to } \\
\text { make good health care decisions }\end{array}$ & $\begin{array}{l}\text { Communication } \\
\text { between family and } \\
\text { care team }\end{array}$ & 23.84 & $\begin{array}{l}\text { Parental PELICAN Questionnaire (Zimmerman, 2015) } \\
\text { [22]; Community PedsCare HRQoL instrument } \\
\text { (Goldhagen, 2016) [24] }\end{array}$ \\
\hline 11. Care team helps me to advocate for my child's & Relationship between & 23.20 & New item (PPHC expert panel, Sept 2018) \\
\hline
\end{tabular}

12. Access to on-call service from palliative care Access to care team or hospice team

Parental Questionnaire 1 (Vollenbroich, 2012) [21]

13. I have access to care provider who can coach Care coordination or guide me to care for my child

14. Care team looks at all of my child's needs

Continuity of care

Quality of Children's Palliative Care Instrument (Widger, 2015) [53]

15. It is easy to contact the care team

Access to care team

20.38

Quality of Children's Palliative Care Instrument (Widger, 2015) [53]

16. Knowledge/skills of nurse(s)

17. Information shared between me and the care team is clear

18. Knowledge/skills of physician(s)

19. Care team provides information about treatments for my child's pain and other symptoms

20. Care team takes time to listen carefully

21. Care team helps me to use non-drug measures to ease my child's pain and other symptoms
Knowledge and skills of care team providers

Communication

between family and care team

Knowledge and skills of care team providers

Physical aspects of care:

Communication

Communication between family and care team

Physical aspects of care: Symptom management
Quality of Children's Palliative Care Instrument (Widger, 2015) [53]

18.72

Parental Questionnaire 1 (Vollenbroich, 2012) [21]

Quality of Children's Palliative Care Instrument (Widger, 2015) [53]

Parental Questionnaire 1 (Vollenbroich, 2012) [21]

17.19

Seattle Pediatric Palliative Care Project evaluation (Hays, 2006) [30]

Consumer Assessment of Healthcare Providers and Systems (CAHPS) Hospice Survey [54] 
Table 4 Items Prioritized by Parents (Phase 3) (Continued)

\begin{tabular}{|c|c|c|c|}
\hline Item $^{a}$ & Domain $^{b}$ & $\begin{array}{l}\text { Weighted } \\
\text { Item } \\
\text { Score }\end{array}$ & Original Instrument \\
\hline 22. Care team is kind, caring, and respectful & $\begin{array}{l}\text { Relationship between } \\
\text { family and care team }\end{array}$ & 13.71 & Bereaved Family Survey [32] \\
\hline $\begin{array}{l}\text { 23. Care team helps me adapt my home to } \\
\text { support my child's care needs }\end{array}$ & Care coordination & 13.38 & IOM 2003 report [17]; NHPCO 2019 standards [26] \\
\hline $\begin{array}{l}\text { 24. Care team provides emotional support for my } \\
\text { child }\end{array}$ & $\begin{array}{l}\text { Psychological/ } \\
\text { emotional aspects of }\end{array}$ & 12.38 & $\begin{array}{l}\text { Quality of Children's Palliative Care Instrument (Widger, } \\
\text { 2015) [53] }\end{array}$ \\
\hline
\end{tabular}

25. Care team provides opportunities for my child to talk about his/her worries and fears

26. Care team helps me hope for best outcome while also helping me prepare in case that outcome does not happen

27. I can talk about my child's end of life with care team

28. Care team has prepared me for what my child's last weeks of life may be like

29. Care team talks with me about my fears and worries

30. My child receives complementary and alternative medicine

31. Care team helps me talk about my child's preferred place of death

32. Care team provides emotional support for my other children

33. Care team helps me cope with the stress of caregiving

34. Care team provides emotional support for me

35. Care team helps me find resources to cope with financial strain

36. Care team helps me talk about whether to stop life-sustaining measures

37. Knowledge/skills of social worker(s)

38. Care team helps me talk with my child about death and dying

39. Care team helps prepare my child for school

40. Care team provides emotional support for my child's extended social network (e.g., classmates, neighbors, extended family)

41. Care team is respectful of my spiritual/religious beliefs

42. Care team is respectful of my cultural beliefs/ practices

\section{Psychological/ emotional aspects of care: Child}

Psychological/ emotional aspects of care: Parent(s)

\section{Communication at} end of life

Caregiver support at $\mathbf{9 . 0 1}$ the end of life

\section{Psychological/ emotional aspects of care: Parent(s)}

Physical aspects of 7.53 care: Symptom management

Communication at end of life

Psychological/ emotional aspects of care: Sibling(s)

Social aspects of care: Parent(s)

Psychological/ emotional aspects of care: Parent(s)

Practical aspects of care

Ethical and legal $\quad 3.76$ aspects of care

Knowledge and skills of care team providers

Communication at end of life

Social aspects of care: Child

Emotional aspects of care: Extended social network

Spiritual, religious, and existential aspects of care

Cultural aspects of $\quad 0.18$ care
New item (developed based on recommendation from dissertation committee; Jan 2019)

Quality of Children's Palliative Care Instrument (Widger, 2015) [53]

Parental Questionnaire 1 (Vollenbroich, 2012) [21]

Parental PELICAN Questionnaire (Zimmerman, 2015) [22]

Parental PELICAN Questionnaire (Zimmerman, 2015) [22]

Parental PELICAN Questionnaire (Zimmerman, 2015) [22]

Quality indicators for paediatric palliative care (Charlebois) [55]

Quality of Children's Palliative Care Instrument (Widger, 2015) [53]

NCP 4th Edition Domains [25]

Quality of Children's Palliative Care Instrument (Widger, 2015) [53]

NCP 4th Edition Domains [25]; Massachusetts PPCN Evaluation (Bona, 2011) [11]

Parental PELICAN Questionnaire (Zimmerman, 2015) [22]

Parental Questionnaire 1 (Vollenbroich, 2012) [21]

Parental Questionnaire 1 (Vollenbroich, 2012) [21]

Seattle Pediatric Palliative Care Project evaluation (Hays, 2006) [30]

New item (PPHC expert panel, Sept 2018)

Bereaved Family Survey [32]

Bereaved Family Survey [32]

${ }^{\mathrm{a}}$ Bolded items were retained for evaluation in next phase based on weighted item scores

${ }^{\mathrm{b}}$ See Table 1 for domain definitions 
services were crucial for managing their children's symptoms and supporting their children's health-related quality of life in the home setting [11, 13, 24, 30].

Another strength is that our instrument also assesses home-specific aspects of care that were not represented in existing instruments. For example, the item, The care team helps adapt our home to better support my child's current care needs, is based on recommendations from the Institute of Medicine [17] and the National Hospice and Palliative Care Organization [26]. Interestingly, several parents in our study spoke not only of the importance of medical equipment and other home adaptations, such as a hospital bed or adaptive chairs, but also the importance of equipment that does not look too "medicalized" and that does not drastically alter the home environment. This is similar to a finding in a previous qualitative study of 12 families with children requiring mechanical ventilation in the home, where parents spoke of the importance of their homes looking "normal," and that medical devices, equipment, and other adaptations (such as elevators or ceiling rails for facilitating mobilization) were camouflaged, hidden, or discrete so that they did not "dominate" the home environment [58]. More work is needed to better understand families' needs in this area.

Another item unique to the home setting is The care team helps me to feel confident in managing my child's symptoms at home without needing to go to the hospital. We adapted this item from two existing studies on community-based PPC [11, 24]. Parents in our study spoke of the importance of having knowledge, supplies, medications, equipment, phone-based or in-person support from providers, and a plan in place when crisis situations arose at home. Parents' confidence and perceived ability to manage their child's illness and care needs have been observed to be an important facilitator of PPHC@Home [10]. Comprehensive programs that provide families access to $24 / 7$ on-call services, care coordination, and home visits by nursing and medical providers support the family's ability to manage symptoms, particularly at the end of life [11, 29, 59]. These programs also help reduce unwanted hospital utilization and facilitate death in the family's preferred location [11, $13,21,24,60]$.

Finally, the item The nurses have the knowledge, skills, and experience to support my child's palliative or hospice care at home was adapted from one existing instrument [21] and informed by NCP Guidelines [25]. The availability of appropriately-trained nurses was a significant issue for many parents in our study. Several parents spoke of challenges in finding nurses who had both end-of-life and pediatric expertise. While home-based palliative and hospice nursing support is especially critical for helping caregivers troubleshoot technical problems and make decisions, and for providing respite care and overall emotional support to the family $[59,61]$, finding adequate palliative and hospice nursing support is often challenging [61-64]. Additionally, home care nurses play a significant role in the home-based care of many children with serious illnesses. Yet, finding adequate skilled and/or private duty nurses is often a significant challenge for families [64-66], which could lead to outcomes such as unintended rehospitalizations [67, 68], increased hospital use [67, 69], and poor parental health and wellbeing [66, 70]. One parent in our study expressed frustration at being eligible for a certain number of skilled nursing hours for her child, but not being able to find nurses to fill those hours: "It's just a sad scenario when you have the hours in place, and then you can't find qualified people to cover them. That's why you end up back in the hospital, right...sometimes you do settle because you need the extra hands because you're just exhausted. Other times, you have to consider the situation and say, oh, we need to be back in the hospital because we're just not going to be able to do it here."

The cognitive interviews, of note, informed the readdition of the item The care team provides support for my other children's feelings and emotions. Several parents spoke of the importance of the team's support for their other children, particularly as siblings may often be very involved in the day-to-day care of the ill sibling in the home. This proximity of siblings to the ill child's care may be particularly important to PPHC provided in the home setting: one qualitative study found that siblings may fill many different roles at home, including playmate, companion, and helper, which included providing direct care such as feeding, toileting, and carrying their sibling from room to room [71]. Although this item was initially removed in Phase 3, this could potentially be attributed to how the item was written and comprehended by participants. Another possible explanation for the lower rating may be attributed to the struggles parents face in balancing the care of the ill child with the child's siblings [71-73]. Specifically, when making a choice between meeting their ill child's and other children's needs, parents may prioritize the ill child's physical and emotional needs, which may be seen as requiring more immediate attention. In either case, meeting siblings' needs is a documented gap in the PPC setting [71, 73], and we agreed with parents in Phase 4 that we should evaluate parents' needs for sibling support by reincorporating this item into the instrument. Future work will need to evaluate if this item adequately addresses siblings' most pressing needs in the home.

This instrument development project has some limitations. First, while we followed a rigorous process of item selection, prioritization, reduction, and cognitive 
Table 5 Final EXPERIENCE@Home Measure

\begin{tabular}{|c|c|c|c|c|c|c|c|}
\hline \multicolumn{8}{|c|}{$\begin{array}{l}\text { Please choose the answer that best fits your experience with your child's home-based palliative or hospice care team over the past week. } \\
\text { Your answers will help the care team to better understand if your child's and family's most important needs are being met, and to guide the care team to better } \\
\text { address those needs. } \\
\text { Note: For all questions, the care team is your child's home-based palliative care or hospice team (that is, the nurses, physicians, social workers, chaplains, child } \\
\text { life therapists, art therapists who care for your child and family in your home). }\end{array}$} \\
\hline 1 & $\begin{array}{l}\text { The care team treats my child's physical symptoms so } \\
\text { that my child has as good a quality of life as possible. }\end{array}$ & $\begin{array}{l}\square \text { Strongly } \\
\text { Agree }\end{array}$ & $\square$ Agree & $\square$ Neutral & $\square$ Disagree & $\begin{array}{l}\square \text { Strongly } \\
\text { Disagree }\end{array}$ & $\begin{array}{l}\square \text { Does not } \\
\text { apply }\end{array}$ \\
\hline 2 & $\begin{array}{l}\text { The care team helps me to feel confident in managing } \\
\text { my child's symptoms at home without needing to go to } \\
\text { the hospital. }\end{array}$ & $\begin{array}{l}\square \text { Strongly } \\
\text { Agree }\end{array}$ & $\square$ Agree & $\square$ Neutral & $\square$ Disagree & $\begin{array}{l}\square \text { Strongly } \\
\text { Disagree }\end{array}$ & $\begin{array}{l}\square \text { Does not } \\
\text { apply }\end{array}$ \\
\hline 3 & $\begin{array}{l}\text { My care team provides the care or guidance we need to } \\
\text { keep the child at home. }\end{array}$ & $\begin{array}{l}\square \text { Strongly } \\
\text { Agree }\end{array}$ & $\square$ Agree & $\square$ Neutral & $\square$ Disagree & $\begin{array}{l}\square \text { Strongly } \\
\text { Disagree }\end{array}$ & $\begin{array}{l}\square \text { Does not } \\
\text { apply }\end{array}$ \\
\hline 4 & I trust the care team. & $\begin{array}{l}\square \text { Strongly } \\
\text { Agree }\end{array}$ & $\square$ Agree & $\square$ Neutral & $\square$ Disagree & $\begin{array}{l}\square \text { Strongly } \\
\text { Disagree }\end{array}$ & $\begin{array}{l}\square \text { Does not } \\
\text { apply }\end{array}$ \\
\hline 5 & $\begin{array}{l}\text { The care team works together with me and my child to } \\
\text { make decisions about my child's medical care at home. }\end{array}$ & $\begin{array}{l}\square \text { Strongly } \\
\text { Agree }\end{array}$ & $\square$ Agree & $\square$ Neutral & $\square$ Disagree & $\begin{array}{l}\square \text { Strongly } \\
\text { Disagree }\end{array}$ & $\begin{array}{l}\square \text { Does not } \\
\text { apply }\end{array}$ \\
\hline 6 & $\begin{array}{l}\text { The care team asks for my opinions and concerns about } \\
\text { my child. }\end{array}$ & $\begin{array}{l}\square \text { Strongly } \\
\text { Agree }\end{array}$ & $\square$ Agree & $\square$ Neutral & $\square$ Disagree & $\begin{array}{l}\square \text { Strongly } \\
\text { Disagree }\end{array}$ & $\begin{array}{l}\square \text { Does not } \\
\text { apply }\end{array}$ \\
\hline 7 & $\begin{array}{l}\text { The palliative care or hospice team works closely with } \\
\text { my child's other providers (for ex, neurology, cardiology, } \\
\text { oncology, primary care) to support our family's goals for } \\
\text { my child's care at home. }\end{array}$ & $\begin{array}{l}\square \text { Strongly } \\
\text { Agree }\end{array}$ & $\square$ Agree & $\square$ Neutral & $\square$ Disagree & $\begin{array}{l}\square \text { Strongly } \\
\text { Disagree }\end{array}$ & $\begin{array}{l}\square \text { Does not } \\
\text { apply }\end{array}$ \\
\hline 8 & $\begin{array}{l}\text { The care team gives me enough information to make } \\
\text { informed health care decisions about my child's care at } \\
\text { home. }\end{array}$ & $\begin{array}{l}\square \text { Strongly } \\
\text { Agree }\end{array}$ & $\square$ Agree & $\square$ Neutral & $\square$ Disagree & $\begin{array}{l}\square \text { Strongly } \\
\text { Disagree }\end{array}$ & $\begin{array}{l}\square \text { Does not } \\
\text { apply }\end{array}$ \\
\hline 9 & $\begin{array}{l}\text { I have regular access to on-call services from our care } \\
\text { team. }\end{array}$ & $\begin{array}{l}\square \text { Strongly } \\
\text { Agree }\end{array}$ & $\square$ Agree & $\square$ Neutral & $\square$ Disagree & $\begin{array}{l}\square \text { Strongly } \\
\text { Disagree }\end{array}$ & $\begin{array}{l}\square \text { Does not } \\
\text { apply }\end{array}$ \\
\hline 10 & $\begin{array}{l}\text { I have access to a provider who can help me coordinate } \\
\text { my child's care at home. }\end{array}$ & $\begin{array}{l}\square \text { Strongly } \\
\text { Agree }\end{array}$ & $\square$ Agree & $\square$ Neutral & $\square$ Disagree & $\begin{array}{l}\square \text { Strongly } \\
\text { Disagree }\end{array}$ & $\begin{array}{l}\square \text { Does not } \\
\text { apply }\end{array}$ \\
\hline 11 & The care team considers all of my child's needs. & $\begin{array}{l}\square \text { Strongly } \\
\text { Agree }\end{array}$ & $\square$ Agree & $\square$ Neutral & $\square$ Disagree & $\begin{array}{l}\square \text { Strongly } \\
\text { Disagree }\end{array}$ & $\begin{array}{l}\square \text { Does not } \\
\text { apply }\end{array}$ \\
\hline 13 & $\begin{array}{l}\text { The doctors and nurse practitioners have the } \\
\text { knowledge, skills, and experience to support my child's } \\
\text { palliative or hospice care at home. }\end{array}$ & $\begin{array}{l}\square \text { Strongly } \\
\text { Agree }\end{array}$ & $\square$ Agree & $\square$ Neutral & $\square$ Disagree & $\begin{array}{l}\square \text { Strongly } \\
\text { Disagree }\end{array}$ & $\begin{array}{l}\square \text { Does not } \\
\text { apply }\end{array}$ \\
\hline 14 & $\begin{array}{l}\text { The care team provides the information and strategies } \\
\text { to effectively manage my child's pain and other physical } \\
\text { symptoms at home. }\end{array}$ & $\begin{array}{l}\square \text { Strongly } \\
\text { Agree }\end{array}$ & $\square$ Agree & $\square$ Neutral & $\square$ Disagree & $\begin{array}{l}\square \text { Strongly } \\
\text { Disagree }\end{array}$ & $\begin{array}{l}\square \text { Does not } \\
\text { apply }\end{array}$ \\
\hline 15 & $\begin{array}{l}\text { The care team helps adapt our home to better support } \\
\text { my child's current care needs. }\end{array}$ & $\begin{array}{l}\square \text { Strongly } \\
\text { Agree }\end{array}$ & $\square$ Agree & $\square$ Neutral & $\square$ Disagree & $\begin{array}{l}\square \text { Strongly } \\
\text { Disagree }\end{array}$ & $\begin{array}{l}\square \text { Does not } \\
\text { apply }\end{array}$ \\
\hline 16 & $\begin{array}{l}\text { The care team provides opportunities for my child to } \\
\text { express his/her feelings, such as fears, worries, and } \\
\text { hopes. }\end{array}$ & $\begin{array}{l}\square \text { Strongly } \\
\text { Agree }\end{array}$ & $\square$ Agree & $\square$ Neutral & $\square$ Disagree & $\begin{array}{l}\square \text { Strongly } \\
\text { Disagree }\end{array}$ & $\begin{array}{l}\square \text { Does not } \\
\text { apply }\end{array}$ \\
\hline 17 & $\begin{array}{l}\text { The care team provides support for my other } \\
\text { children's feelings and emotions. }\end{array}$ & $\begin{array}{l}\square \text { Strongly } \\
\text { Agree }\end{array}$ & $\square$ Agree & $\square$ Neutral & $\square$ Disagree & $\begin{array}{l}\square \text { Strongly } \\
\text { Disagree }\end{array}$ & $\begin{array}{l}\square \text { Does not } \\
\text { apply }\end{array}$ \\
\hline 18 & $\begin{array}{l}\text { The care team provides support for my feelings and } \\
\text { emotions, including fear, worry, sadness, and hope. }\end{array}$ & $\begin{array}{l}\square \text { Strongly } \\
\text { Agree }\end{array}$ & $\square$ Agree & $\square$ Neutral & $\square$ Disagree & $\begin{array}{l}\square \text { Strongly } \\
\text { Disagree }\end{array}$ & $\begin{array}{l}\square \text { Does not } \\
\text { apply }\end{array}$ \\
\hline 19 & $\begin{array}{l}\text { The care team helps me hope for the best possible } \\
\text { outcome for my child's health, while also helping me } \\
\text { prepare if that outcome doesn't happen. }\end{array}$ & $\begin{array}{l}\square \text { Strongly } \\
\text { Agree }\end{array}$ & $\square$ Agree & $\square$ Neutral & $\square$ Disagree & $\begin{array}{l}\square \text { Strongly } \\
\text { Disagree }\end{array}$ & $\begin{array}{l}\square \text { Does not } \\
\text { apply }\end{array}$ \\
\hline 20 & $\begin{array}{l}\text { The care team has provided or directed me to } \\
\text { resources that support my needs as my child's } \\
\text { caregiver. }\end{array}$ & $\begin{array}{l}\square \text { Strongly } \\
\text { Agree }\end{array}$ & $\square$ Agree & $\square$ Neutral & $\square$ Disagree & $\begin{array}{l}\square \text { Strongly } \\
\text { Disagree }\end{array}$ & $\begin{array}{l}\square \text { Does not } \\
\text { apply }\end{array}$ \\
\hline 21 & I can talk about my child's end of life with the care team. & $\begin{array}{l}\square \text { Strongly } \\
\text { Agree }\end{array}$ & $\square$ Agree & $\square$ Neutral & $\square$ Disagree & $\begin{array}{l}\square \text { Strongly } \\
\text { Disagree }\end{array}$ & $\begin{array}{l}\square \text { Does not } \\
\text { apply }\end{array}$ \\
\hline 22 & $\begin{array}{l}\text { The care team has talked with me about my child's last } \\
\text { weeks of life and what they may be like. }\end{array}$ & $\begin{array}{l}\square \text { Strongly } \\
\text { Agree }\end{array}$ & $\square$ Agree & $\square$ Neutral & $\square$ Disagree & $\begin{array}{l}\square \text { Strongly } \\
\text { Disagree }\end{array}$ & $\begin{array}{l}\square \text { Does not } \\
\text { apply }\end{array}$ \\
\hline
\end{tabular}


interviewing, we may have missed or excluded important items or domains from our instrument. Our findings should not be interpreted to diminish critically-important aspects of PPHC@Home, as we know that high-quality PPC includes interdisciplinary care across the spectrum of care domains. Instead, our instrument represents the domains and associated items we have identified, through a multi-phased, multi-method approach, that are the most highlyprioritized for PPHC@Home by our sample of PPC professionals and parents. We will, however, continue to evaluate the content validity of the instrument in future work. Second, our PPC professional sample was relatively socio-demographically homogenous, although it does reflect the overall demographic profile of hospice and palliative physicians [74] and the nursing workforce more generally [75] in the U.S. Furthermore, professional participants represented several different professions, including parent advocates, nurses, physicians, social workers, chaplains, and expressive therapists. The sociodemographic profile of parent participants was also relatively homogenous, although not surprising given issues with gender [76, 77] and racial and ethnic minority [78] imbalance in PPC studies, as well as racial and ethnic disparities in access to home-based hospice care [79]. We did, however, include parents of children with diverse diseases, and we also recruited a diverse sample with regard to illness trajectories by including parents whose children were currently receiving care, as well as bereaved parents. Additionally, both the professional and the parent samples came from a wide range of geographic regions, institutions, and care models. Nonetheless, it will be important to recruit a greater representation of fathers, racial and ethnic minorities, and persons from varying socioeconomic and educational backgrounds in future work. Third, because we recruited a portion of our parent participants from an online network, we were unable to assess our nonresponse rate and potential differences in how responders compared to non-responders. In our CHOPbased parents, however, reasons for non-participation typically related to being too busy or their child being too sick at the time of the study.

\section{Conclusions}

Through a phased, multi-method, multi-stakeholder instrument development process, we have developed the 22-item EXPERIENCE@Home Measure, which is the first known to specifically measure family-reported experiences with PPHC@Home in the U.S. The next steps in the assessment and refinement of this measure will include psychometric testing with a larger sample of parents of seriously-ill children receiving care at home, as well as an evaluation of the clinical utility of the instrument with PPHC providers for providing real-time, family-reported feedback to palliative care and hospice teams. While this further evaluation work is ongoing, we have developed a new instrument using rigorous methods that promises to be clinically useful for children with serious illness and their families. Our parent participants reiterated the importance of having a way to provide feedback about their care experiences at home to their providers. As one parent told us, "I think it would be a really effective tool... it just gives families like a, I don't know, some agency over like what's happening, and I think it's a good thing."

\section{Supplementary Information}

The online version contains supplementary material available at https://doi. org/10.1186/s12904-020-00703-0.

Additional file 1:. Items Prioritized by PPHC Professionals (Phase 2) $[80,81]$.

Additional file 2:. Demographic and Clinical Characteristics of Parent Participants and Their Children (Phase 4).

\section{Abbreviations \\ PPC: Pediatric palliative care; PPHC: Pediatric palliative and hospice care; PPHC@Home: Pediatric palliative and hospice care at home; NCP: National Consensus Project; DCE: Discrete choice experiment; CHOP: Children's Hospital of Philadelphia; PACT: Pediatric Advanced Care Team; CPN: Courageous Parents Network; SE: Standard error; EXPERIENCE@Home: Experiences of Palliative and Hospice Care for Children and Caregivers at Home Measure}

\section{Acknowledgements}

The authors would like to acknowledge the Children's Hospital of Philadelphia's Justin Michael Ingerman Center for Palliative Care and the Courageous Parents Network, who supported the design and data collection phases of this study. In particular, we would like to thank Ms. Karen Crew and Ms. Dana Dombrowski for their guidance and effort on this project. We would also like to thank Ms. Solim Lee, Ms. Heather Carlino, and Dr. Patricia Pawlow from the University of Pennsylvania School of Nursing for their assistance with piloting the cognitive interviews. We would like to acknowledge all of the clinicians, parent advocates, and researchers who shared their time and expertise with us. And finally, we would like to acknowledge the parents who so generously gave their time and energy to participate in this project. We are deeply grateful for their willingness to share their perspectives with us and to help us work toward advancing the quality of care provided in the home setting for future children and families.

\section{Authors' contributions}

$J B$ was the principal investigator and was primarily responsible for the design, conduction (including data collection, analysis, and interpretation), and write-up of this manuscript. Only JB had full access to the data collected. ME was the dissertation chair and oversaw all aspects of the study design, conduction, and manuscript write-up. ME, CF, JD, and KW were dissertation committee members and were involved in the study conceptualization and design, had access to de-identified data, and were directly involved with data analysis and interpretation. GL and BL were involved in the study design and interpretation of results. All authors revised drafts critically for important intellectual content, and read and approved the final manuscript. Each author agreed to be accountable for all aspects of the work in ensuring that questions related to the accuracy or integrity of any part of the work are appropriately investigated and resolved. 


\section{Funding}

Research reported in this publication was supported by the National Institute of Nursing Research of the National Institutes of Health under Award Number F31NR017554. The content is solely the responsibility of the authors and does not necessarily represent the official views of the National Institutes of Health. Additional research funding was provided by the University of Pennsylvania School of Nursing Office of Nursing Research Student Research Grant, the Independence Blue Cross Foundation Nurses for Tomorrow Scholars Program, and the Sawtooth Software Academic Grant. Funders were not involved in the design of the study; in data collection, analysis, or interpretation; or in writing the manuscript.

\section{Availability of data and materials}

The datasets used and/or analyzed during the current study are available from the corresponding author on reasonable request.

\section{Ethics approval and consent to participate}

The Children's Hospital of Philadelphia's (CHOP) Institutional Review Board approved this study. All partipcants provided their electronic informed consent to participate.

\section{Consent for publication}

Not applicable.

\section{Competing interests}

The authors declare that they have no competing interests.

\section{Author details}

${ }^{1}$ School of Nursing, University of Pennsylvania, 418 Curie Blvd, Philadelphia, PA 19104, USA. ²Children's Hospital of Philadelphia, 3401 Civic Center Blvd, Philadelphia, PA, USA. ${ }^{3}$ Perelman School of Medicine, University of Pennsylvania, 3400 Civic Center Blvd, Philadelphia, PA, USA. ${ }^{4}$ Lawrence S. Bloomberg Faculty of Nursing, University of Toronto, 155 College Street, Toronto, Ontario, Canada. ${ }^{5}$ Hospital for Sick Children, 555 University Avenue, Toronto, Ontario, Canada. ${ }^{6}$ Courageous Parents Network, Newton, MA, USA. ${ }^{7}$ Corporal Michael J. Crescenz VA Medical Center, 21 S University Ave, Philadelphia, PA, USA.

\section{Received: 7 August 2020 Accepted: 28 December 2020}

\section{Published online: 14 January 2021}

\section{References}

1. Feudtner C, Friebert S, Jewell J. Pediatric palliative care and hospice care commitments, guidelines, and recommendations. Pediatr. 2013;132(5):96672.

2. Feudtner C, Feinstein JA, Satchell M, Zhao H, Kang TI. Shifting place of death among children with complex chronic conditions in the United States, 1989-2003. JAMA. 2007;297(24):2725-32.

3. Feudtner C, Kang TI, Hexem KR, Friedrichsdorf SJ, Osenga K, Siden H, et al. Pediatric palliative care patients: A prospective multicenter cohort study. Pediatr. 2011;127(6):1094-101.

4. Burke RT, Alverson B. Impact of children with medically complex conditions. Pediatr. 2010;126(4):789-90

5. Feudtner C, Silveira MJ, Christakis DA. Where do children with complex chronic conditions die? Patterns in Washington State, 1980-1998. Pediatr. 2002;109(4):656-60.

6. Friebert S, Williams C. NHPCO'S Facts and Figures: Pediatric Palliative and Hospice Care in America. Alexandria: NHPCO; 2015

7. Feudtner C, Hays RM, Haynes G, Geyer JR, Neff JM, Koepsell TD. Deaths attributed to pediatric complex chronic conditions: National trends and implications for supportive care services. Pediatr. 2001;107(6):E99.

8. Nageswaran S, Radulovic A, Anania A. Transitions to and from the acute inpatient care setting for children with life-threatening illness. Pediatr Clin N Am. 2014;61(4):761-83.

9. Kaye E, Rubenstein J, Levine D, Baker JN, Dabbs D, Friebert S. Pediatric palliative care in the community. CA Cancer J Clin. 2015;65:315-33.

10. Boyden JY, Curley MAQ, Deatrick JA, Ersek M. Factors associated with the use of U.S. community-based palliative care for children with life-limiting or life-threatening illnesses and their families: An integrative review. J Pain Symptom Manag. 2018;55(1):117-31.
11. Bona K, Bates J, Wolfe J. Massachusetts' Pediatric Palliative Care Network: Successful implementation of a novel state-funded pediatric palliative care program. J Palliat Med. 2011;14(11):1217-23.

12. Knapp CA, Madden VL, Curtis CM, Sloyer PJ, Huang IC, Thompson LA, et al. Partners in Care: Together for Kids: Florida's model of pediatric palliative care. J Palliat Med. 2008;11(9):1212-20.

13. Friedrichsdorf SJ, Postier A, Dreyfus J, Osenga K, Sencer S, Wolfe J. Improved quality of life at end of life related to home-based palliative care in children with cancer. J Palliat Med. 2015;18(2):143-50.

14. Thienprayoon R, Grossoehme D, Humphrey L, Pestian T, Frimpong-Manso M, Malcolm H, et al. "There's Just No Way to Help, and They Did." Parents name Compassionate Care as a new domain of quality in pediatric homebased hospice and palliative care. J Palliat Med. 2020;23(6):767-76.

15. Lindley LC, Lyon ME. A profile of children with complex chronic conditions at end of life among Medicaid beneficiaries: Implications for health care reform. J Palliat Med. 2013;16(11):1388-93.

16. Carroll JM, Santucci G, Kang TI, Feudtner C. Partners in Pediatric Palliative Care: A program to enhance collaboration between hospital and community palliative care services. Amer J Hosp Palliat Med. 2007;24(3):1915.

17. Field MJ, Behrman RE. When Children Die: Improving Palliative and End-ofLife care for Children and their Families. Washington, DC: The National Academies Press; 2003. Available from: https://www.nap.edu/catalog/10390/ when-children-die-improving-palliative-and-end-of-life-care. Accessed 27 July 2020.

18. Conway PH, Mostashari F, Clancy C. The future of quality measurement for improvement and accountability. JAMA. 2013;309(21):2215-6.

19. Snyder CF, Aaronson NK, Choucair AK, Elliott TE, Greenhalgh J, Halyard MY, et al. Implementing patient-reported outcomes assessment in clinical practice: A review of the options and considerations. Qual Life Res. 2012; 21(8):1305-14.

20. Widger K, Brennenstuhl S, Duc J, Tourangeau A, Rapoport A. Factor structure of the Quality of Children's Palliative Care Instrument (QCPCI) when completed by parents of children with cancer. BMC Palliat Care. 2019; 18(1):23.

21. Vollenbroich R, Duroux A, Grasser M, Brandstatter M, Borasio GD, Fuhrer M. Effectiveness of a pediatric palliative home care team as experienced by parents and health care professionals. J Palliat Med. 2012;15(3):294-300.

22. Zimmermann K, Cignacco E, Eskola K, Engberg S, Ramelet A-S, Von der Weid N, et al. Development and initial validation of the Parental PELICAN Questionnaire (PaPEQu): An instrument to assess parental experiences and needs during their child's end-of-life care. J Adv Nurs. 2015;71(12):3006-17.

23. Linton JM, Feudtner C. What accounts for differences or disparities in pediatric palliative and end-of-life care? A systematic review focusing on possible multilevel mechanisms. Pediatr. 2008;122:574-82.

24. Goldhagen J, Fafard M, Komatz K, Eason T, Livingood WC. Communitybased pediatric palliative care for health related quality of life, hospital utilization and costs lessons learned from a pilot study. BMC Palliat Care. 2016;15:73.

25. National Consensus Project for Quality Palliative Care. Clinical Practice Guidelines for Quality Palliative Care: National Coalition for Hospice and Palliative Care. Richmond: National Coalition For Hospice \& Palliative Care; 2018. https://www.nationalcoalitionhpc.org/ncp/. Accessed 5 June 2020.

26. National Hospice and Palliative Care Organization (NHPCO). Standards of practice for pediatric palliative care. 2019. https://www.nhpco.org/wpcontent/uploads/2019/07/Pediatric_Standards.pdf. Accessed 12 June 2020.

27. Thienprayoon R, Mark MSJ, Grossoehme D. Provider-prioritized domains of quality in pediatric home-based hospice and palliative care: A study of the Ohio Pediatric Palliative Care and End-of-Life Network. J Palliat Med. 2018; 31(3):290-6.

28. Gans D, Kominski GF, Roby DH, Diamant AL, Chen X, Lin W, et al. Better outcomes, lower costs: Palliative care program reduces stress, costs of care for children with life-threatening conditions. Los Angeles: UCLA Center for Health Policy Research; 2012. http://healthpolicy.ucla.edu/publications/ search/pages/detail.aspx?Pub|D=1087. Accessed 6 Jan 2021.

29. Thienprayoon R, Marks E, Funes M, Martinez-Puente LM, Winick N, Lee SC Perceptions of the pediatric hospice experience among English- and Spanish-speaking families. J Palliat Med. 2016;19(1):30-41.

30. Hays RM, Valentine J, Haynes G, Geyer JR, Villareale N, McKinstry B, et al. The Seattle Pediatric Palliative Care Project: Effects on family satisfaction and health-related quality of life. J Palliat Med. 2006;9(3):716-28. 
31. Anhang Price R, Stucky B, Parast L, Elliott MN, Haas A, Bradley M, et al. Development of valid and reliable measures of patient and family experiences of hospice care for public reporting. J Palliat Med. 2018;21(7):924-32.

32. Kutney-Lee A, Carpenter J, Smith D, Thorpe J, Tudose A, Ersek M. Case-mix adjustment of the Bereaved Family Survey. Amer J Hosp Palliat Med. 2018; 35(7):1015-22.

33. Gomes B, de Brito M, Sarmento VP, Yi D, Soares D, Fernandes J, et al. Valuing attributes of home palliative care with service users: A pilot discrete choice experiment. J Pain Symptom Manag. 2017;54(6):973-85.

34. Huynh E, Coast J, Rose J, Kinghorn P, Flynn T. Values for the ICECAPSupportive Care Measure (ICECAP-SCM) for use in economic evaluation at end of life. Soc Sci Med. 2017;189:114-28.

35. Mangham LJ, Hanson K, McPake B. How to do (or not to do) ... Designing a discrete choice experiment for application in a low-income country. Health Policy Plan. 2009;24(2):151-8.

36. Ryan M, Gerard K, Amaya-Amaya M. In: Bateman IJ, editor. Using Discrete Choice Experiments to Value Health and Health Care. The Netherlands: Springer; 2008.

37. Feudtner C, Walter JK, Faerber JA, Hill DL, Carroll KW, Mollen CJ, et al. Goodparent beliefs of parents of seriously ill children. JAMA Pediatr. 2015;169(1): 39-47.

38. October TW, Fisher K, Feudtner C, Hinds PS. The parent perspective: "being a good parent" when making critical decisions in the PICU. Pediatr Crit Care Med. 2014;15(4):291-8

39. Cohen SH. Maximum difference scaling: Improved measures of importance and preference for segmentation. Sequim: Sawtooth Software; 2003. https:// www.sawtoothsoftware.com/support/technical-papers/maxdiff-best-worstscaling/maximum-difference-scaling-improved-measures-of-importance-andpreference-for-segmentation-2003. Accessed 27 July 2020.

40. Louviere JJ, Flynn TN, Carson RT. Discrete choice experiments are not conjoint analysis. J Choice Model. 2010;3(3):57-72.

41. Malcolm C, Knighting K, Forbat L, Kearney N. Prioritisation of future research topics for children's hospice care by its key stakeholders: A Delphi study. Palliat Med. 2009;23(5):398-405.

42. Chrazan K, Orme B. Applied MaxDiff: a practitioner's guide to best-worst scaling. Provo: Sawtooth Software, Inc.; 2019.

43. Sawtooth Software. Bandit MaxDiff: When to use it and why it can be a better choice than standard MaxDiff. 2018. https://www.sawtoothsoftware. com/support/technical-papers/maxdiff-best-worst-scaling/175-support/ technical-papers/maxdiff-best-worst-scaling/1943-bandit-maxdiff-when-touse-it-and-why-it-can-be-a-better-choice-than-standard-maxdiff. Accessed 30 June 2020.

44. EWd B-G, Donkers B, Jonker MF, Stolk EA. Sample size requirements for discrete-choice experiments in healthcare: A practical guide. Patient. 2015; 8(5):373-84.

45. Lancsar $E$, Louviere J. Conducting discrete choice experiments to inform healthcare decision making. Pharmacoeconomics. 2008;26(8):661-77.

46. Flynn TN, Louviere JJ, Peters TJ, Coast J. Best-worst scaling: What it can do for health care research and how to do it. J Health Econ. 2007;26(1):171-89.

47. Sawtooth Software. Aggregate score estimation via logit analysis. Orem: Sawtooth Software; 2018. https://www.sawtoothsoftware.com/help/ lighthouse-studio/manual/maxdiff_aggregate_logit_analysis.html. Accessed 30 June 2020

48. Bentley B, O'Connor M. Conducting research interviews with bereaved family carers: When do we ask? J Palliat Med. 2015;18(3):241-5.

49. Hynson JL, Aroni R, Bauld C, Sawyer S. Research with bereaved parents: A question of how not why. Palliat Med. 2006;20:805-11.

50. Casarett DJ, Crowley R, Hirschman KB. Surveys to assess satisfaction with endof-life care: Does timing matter? J Pain Symptom Manag. 2003;25(2):128-32.

51. Addington-Hall J, MCPherson C. After-death interviews with surrogates/ bereaved family members: Some issues of validity. J Pain Symptom Manag. 2001;22(3):784-90.

52. Boyden JY, Ersek M, Deatrick JA, Widger K, LaRagione G, Lord B, Feudtner C. What do parents value regarding home-based pediatric palliative and hospice care? J Pain Symptom Manage. 2021;61(1):12-23.

53. Widger K, Tourangeau AE, Steele R, Streiner DL. Initial development and psychometric testing of an instrument to measure the quality of children's end-of-life care. BMC Palliat Care. 2015;14(1):1.

54. CAHPS. Hospice Survey: Frequently asked questions. Baltimore: Centers for Medicare \& Medicaid Services; 2019. https://hospicecahpssurvey.org/en/ hospice-specific-faqs2/\#Q8. Accessed 30 June 2020
55. Charlebois J, Cyr C. Quality indicators for paediatric palliative care. Paediat Child Health. 2015;20(3):145-7.

56. Knafl K, Deatrick J, Gallo A, Holcombe G, Bakitas M, Dixon J, et al. The analysis and interpretation of cognitive interviews for instrument development. Res Nurs Health. 2007;30(2):224-34.

57. Donnelly JP, Downing K, Cloen J, Fragen P, Gupton AW, Misasi J, et al. Development and assessment of a measure of parent and child needs in pediatric palliative care. J Pain Symptom Manag. 2017:55(4):1077-84.

58. Carnevale FA, Alexander E, Davis M, Rennick J, Troini R. Daily living with distress and enrichment: The moral experience of families with ventilatorassisted children at home. Pediatr. 2006;117(1):e48

59. Davies B, Gudmundsdottir M, Worden B, Orloff S, Sumner L, Brenner P. "Living in the dragon's shadow" fathers' experiences of a child's life-limiting illness. Death Stud. 2004;28(2):111-35.

60. Postier A, Chrastek J, Nugent S, Osenga K, Friedrichsdorf SJ. Exposure to home-based pediatric palliative and hospice care and its impact on hospital and emergency care charges at a single institution. J Palliat Med. 2014;17(2): 183-8.

61. Bee PE, Barnes P, Luker KA. A systematic review of informal caregivers' needs in providing home-based end-of-life care to people with cancer. J Clin Nurs. 2009:18(10):1379-93.

62. Rehm RS, Bradley JF. Normalization in families raising a child who is medically fragile/technology dependent and developmentally delayed. Qual Health Res. 2005;15(6):807-20.

63. Varela AMS, Deal AM, Hanson LC, Blatt J, Gold S, Dellon EP. Barriers to hospice for children as perceived by hospice organizations in North Carolina. Amer J Hospice Palliat Care. 2012;29(3):171-6.

64. Kaye EC, Gattas M, Kiefer A, Reynolds J, Zalud K, Li C, et al. Provision of palliative and hospice care to children in the community: A population study of hospice nurses. J Pain Symptom Manag. 2019;57(2):241-50.

65. Weaver MS, Wichman B, Bace S, Schroeder D, Vail C, Wichman C, et al. Measuring the impact of the home health nursing shortage on family caregivers of children receiving palliative care. J Hosp Palliat Nurs. 2018;20(3):260-5.

66. Meltzer LJ, Boroughs DS, Downes JJ. The relationship between home nursing coverage, sleep, and daytime functioning in parents of ventilatorassisted children. J Pediatr Nurs. 2010;25(4):250-7.

67. Gay JC, Thurm CW, Hall M, Fassino MJ, Fowler L, Palusci JV, et al. Home health nursing care and hospital use for medically complex children. Pediatr. 2016;138(5):e20160530.

68. Sobotka SA, Lynch E, Peek ME, Graham RJ. Readmission drivers for children with medical complexity: Home nursing shortages cause health crises. Pediatr Pulmonol. 2020;55(6):1474-80.

69. Boss RD, Williams EP, Henderson CM, Seltzer RR, Shapiro MC, Hahn E, et al. Pediatric chronic critical illness: Reducing excess hospitalizations. Hosp Pediatr. 2017;7(8):460-70

70. Caicedo C. Health and functioning of families of children with special health care needs cared for in home care, long-term care, and medical day care settings. J Dev Behav Pediatr. 2015;36:352-61.

71. Eaton Russell C, Widger K, Beaune L, Neville A, Cadell S, Steele R, et al. Siblings' voices: A prospective investigation of experiences with a dying child. Death Stud. 2018;42(3):184-94.

72. Mooney-Doyle K, Deatrick JA. Parenting in the face of childhood lifethreatening conditions: The ordinary in the context of the extraordinary. Palliat Support Care. 2016;14(3):187-98.

73. Verberne LM, Kars MC, Schouten-van Meeteren AY, Bosman DK, Colenbrander DA, Grootenhuis MA, et al. Aims and tasks in parental caregiving for children receiving palliative care at home: a qualitative study. Eur J Pediatr. 2017;176(3):343-54

74. Salsberg E, Mehfoud N, Quigley L, Lupu D. A profile of active hospice and palliative medicine physicians, 2016. Washington: American Academy of Hospice and Palliative Medicine \& Health Workforce Institute, The George Washington University; 2017. http://aahpm.org/uploads/Profile_of_Active_ HPM_Physicians_September_2017.pdf. Accessed 30 June 2020.

75. Nursing workforce projections by ethnicity and race 2014-2030. HRSA Health Workforce. 2017. https://bhw.hrsa.gov/sites/default/files/bhw/healthworkforce-analysis/research/projections/hrsa-bhw-rn-Ipn-factsheet-12-17.pdf. Accessed 30 June 2020.

76. Hinds PS, Burghen EA, Pritchard M. Conducting end-of-life studies in pediatric oncology. West J Nurs Res. 2007;29(4):448-65.

77. Macdonald ME, Chilibeck G, Affleck W, Cadell S. Gender imbalance in pediatric palliative care research samples. Palliat Med. 2010;24(4):435-44. 
78. Knapp CA, Madden VL, Curtis C, Sloyer PJ, Shenkman EA. Assessing nonresponse bias in pediatric palliative care research. Palliat Med. 2010;24(3):340-7.

79. Cohen LL. Racial/ethnic disparities in hospice care: A systematic review. J Palliat Med. 2008;11(5):763-8.

80. Widger KA, Wilkins K. What are the key components of quality perinatal and pediatric end-of-life care? A literature review. J Palliat Care. 2004;20(2):10512.

81. Hinds PS, Menard JC, Jacobs SS. The child's voice in pediatric palliative and end-of-life care. Prog Palliat Care. 2012;20(6):337-42.

\section{Publisher's Note}

Springer Nature remains neutral with regard to jurisdictional claims in published maps and institutional affiliations.

Ready to submit your research? Choose BMC and benefit from:

- fast, convenient online submission

- thorough peer review by experienced researchers in your field

- rapid publication on acceptance

- support for research data, including large and complex data types

- gold Open Access which fosters wider collaboration and increased citations

- maximum visibility for your research: over $100 \mathrm{M}$ website views per year

At BMC, research is always in progress.

Learn more biomedcentral.com/submissions 